Article

\title{
Overexpression of AtWRKY30 Transcription Factor Enhances Heat and Drought Stress Tolerance in Wheat (Triticum aestivum L.)
}

\author{
Mohamed A. El-Esawi ${ }^{1, *(\mathbb{D}}$, Abdullah A. Al-Ghamdi ${ }^{2}$, Hayssam M. Ali ${ }^{2,3}$ and \\ Margaret Ahmad 4,5 \\ 1 Botany Department, Faculty of Science, Tanta University, Tanta 31527, Egypt \\ 2 Botany and Microbiology Department, College of Science, King Saud University, P.O. Box 2455, \\ Riyadh 11451, Saudi Arabia; abdaalghamdi@ksu.edu.sa (A.A.A.-G.); hayhassan@ksu.edu.sa (H.M.A.) \\ 3 Timber Trees Research Department, Sabahia Horticulture Research Station, Horticulture Research Institute, \\ Agriculture Research Center, Alexandria 21526, Egypt \\ 4 UMR CNRS 8256 (B2A), Université Paris VI, 75005 Paris, France; margaret.ahmad@upmc.fr \\ 5 Department of Biology, Xavier University, Cincinnati, OH 45207, USA \\ * Correspondence: mohamed.elesawi@science.tanta.edu.eg; Tel.: +20-40-334-435-2
}

Received: 12 December 2018; Accepted: 23 January 2019; Published: 20 February 2019

\begin{abstract}
Drought and heat factors have negative impacts on wheat yield and growth worldwide. Improving wheat tolerance to heat and drought stress is of the utmost importance to maintain crop yield. WRKY transcription factors help improve plant resistance to environmental factors. In this investigation, Arabidopsis WRKY30 (AtWRKY30) transcription factor was cloned and expressed in wheat. Plants growth, biomass, gas-exchange attributes, chlorophyll content, relative water content, prolines content, soluble proteins content, soluble sugars content, and antioxidant enzymes activities (catalase (CAT), superoxide dismutase (SOD), peroxidase (POX), and ascorbate peroxidase (APX)) of the AtWRKY30-overexpressing wheat plants were higher than those of the wild type. However, levels of electrolyte leakage, malondialdehyde, and hydrogen peroxide of the AtWRKY30-overexpressing wheat plants were significantly less than those of the wild-type. Additionally, the expression level of antioxidant enzyme-encoding genes and stress-responsive genes (ERF5a, DREB1, DREB3, WRKY19, $T I P 2$, and $A Q P 7)$ were significantly induced in the transgenic wheat plants in comparison with the wild type. In conclusion, the results demonstrated that AtWRKY30 overexpression promotes heat and drought tolerance in wheat by inducing gas-exchange attributes, antioxidant machinery, osmolytes biosynthesis, and stress-related gene expression. AtWRKY30 could serve as a potential candidate gene for improving stress tolerance in wheat.
\end{abstract}

Keywords: wheat; AtWRKY30; heat; drought; antioxidant machinery; gene expression

\section{Introduction}

Abiotic stress factors such as heat and drought restrict crop productivity worldwide [1]. Abiotic stresses affect various physiological processes, leading to the over-production of toxic reactive oxygen species (ROS) in plant cells, thereby inducing oxidative damage [2-6]. Plants adapt through morphological, physiological, and genetic responses to overcome these harmful effects [7-10]. These adaptations include modulating antioxidant systems, root system architecture, and compatible solutes. Plant growth regulators and biostimulants have been applied to mitigate the adverse effects of abiotic stresses in different plant species [11-22]. Additionally, the transgenic approach via the overexpression of certain genes and transcription factors has proven useful in enhancing the tolerance of crops to adverse environmental stresses by the induction of downstream stress-related genes [23,24]. 
For instance, WRKY transcription factor family is significantly induced under stress conditions [25]. The WRKY factors also regulate the downstream-related genes and have a key role in various processes in plant species, including coping with environmental stresses [26-28], leaf senescence [29], and seed development [30]. Several studies have reported that WRKY-encoding genes could be stimulated by low temperatures, salt, drought, ethylene, salicylic acid, methyl jasmonate, abscisic acid, and hydrogen peroxide [31-33]. Additionally, overexpressing WRKY factors promoted plant tolerance to various environmental factors. For instance, OsWRKY11 overexpression promoted drought and heat resistance in rice [34]. The overexpression of cotton genes such as GhWRKY34, GhWRKY17, and GhWRKY41 also augmented salt and drought resistance in Nicotiana benthamiana $[32,35,36]$. Furthermore, the overexpression of wheat genes such as TaWRKY93 and TaWRKY19 augmented salt and drought resistance in Arabidopsis [37,38]. DgWRKY4 overexpression improved salinity tolerance in chrysanthemum [39]. These transcription factors augmented plant tolerance to abiotic stresses by scavenging ROS, accumulating osmolytes, activating stress-responsive genes, and maintaining osmotic adjustment, membrane stability, and ion homeostasis [39]. However, the functions of many WRKY factors have yet to be validated in the majority of non-model plant species, particularly wheat. For instance, AtWRKY30 gene expression conferred enhanced oxidative and salt stress tolerance in the model plant species Arabidopsis [40], but its function has not yet been validated or confirmed in non-model species.

Wheat (Triticum aestioum L.) represents one of the most essential food crops worldwide. Wheat productivity is influenced by drought and heat stresses in several regions. Various reports have revealed the important uses of the transgenic approach in augmenting drought and heat tolerance in wheat. Gao et al. [41] revealed that TaWRKY2 overexpression augmented drought tolerance in wheat. Yu et al. [42] also demonstrated enhanced drought resistance levels in wheat lines overexpressing the bacterial SeCspA gene. AtHDG11 overexpression improved drought tolerance in wheat [43]. Furthermore, the overexpression of TaFER-5B enhanced heat tolerance in wheat [44]. Zang et al. [45] also demonstrated that TaPEPKR2 overexpression improved heat tolerance in wheat lines. However, further enhancement of heat and drought tolerance of wheat crops, through developing and breeding new stress-tolerant varieties, is essential to meet the food needs of the increasing population worldwide. Therefore, the current study aimed to investigate the functional role of AtWRKY30 in promoting heat and drought tolerance in wheat as a non-model important crop. AtWRKY30 was overexpressed in wheat, and various physiological, biochemical, and gene expression analyses were conducted for wild type and transgenic wheat in order to assess the performance of transgenic wheat lines under heat and drought conditions.

\section{Materials and Methods}

\subsection{Plant Materials and Growth Conditions}

Wheat (Triticum aestivum L.) Sakha-61 genotype received from the Agricultural Research Center in Egypt and the wild-type Arabidopsis thaliana (Col-0) received from the University of Paris VI in France were used in this study. Wheat and Arabidopsis seeds were surface-sterilized and left to grow at $24^{\circ} \mathrm{C}$ for 5 days. Germinated seedlings were then transferred into mixed soil comprising equal volumes of peat, sand, and perlite. The seedlings were left to grow with regular irrigation under a regime of $25 / 19^{\circ} \mathrm{C}, 16 / 8 \mathrm{~h}$, and a humidity of $65 \%$.

\subsection{Plasmid Construction and Wheat Transformation}

Total RNA was extracted from Arabidopsis flower using RNeasy Plant Mini kit (Qiagen, Hilden, Germany). Full cDNA was synthesized by a Qiagen Reverse Transcription kit. AtWRKY30 coding region was then amplified and cloned, as previously reported by Scarpeci at al. [40]. In brief, AtWRKY30 cDNA was inserted into pBinAR vector and the generated constructs (pBinAR::AtWRKY30) were transferred into Agrobacterium tumefaciens (EHA105). The resulting recombinant strain harboring the 
constructs was utilized to transform wheat Sakha-61 plants according to the Agrobacterium-mediated transformation method [46].

\subsection{Validation Analysis of Transgenic Wheat Plants}

$\mathrm{T}_{0}$ and $\mathrm{T}_{2}$ homozygous transgenic wheat genotypes were verified by quantifying the expression of AtWRKY30 in the positive transgenics using quantitative real-time PCR (qRT-PCR). The isolation of RNA and synthesis of cDNA were conducted from the wild-type and $T_{0}$ and $T_{2}$ transgenic wheat genotypes, as described before. PCR reactions were carried out in triplicate by following the QuantiTect SYBR Green PCR kit manufacturer's protocol. PCR conditions previously reported by Scarpeci et al. [40] were used. Specific primer pairs previously designed for AtWRKY30 and the reference housekeeping gene PP2A [40] were used in amplification. AtWRKY30 expression was calculated based on the $2^{-\Delta \Delta C t}$ method.

\subsection{Heat and Drought Stress Treatment}

Seedlings of the wild-type and two $\mathrm{T}_{2}$ homozygous AtWRKY30-overexpressing wheat genotypes (OE-4, OE-6) were transferred into pots comprising the aforementioned mixed soil and were left to grow for 2 weeks with daily water irrigation under the same conditions as those described above. The wheat plants were then divided into three groups and were exposed to the following treatments: (1) control plants, $25 / 19{ }^{\circ} \mathrm{C}$ (day/light) with daily irrigation; (2) heat-stressed plants, $40 / 33{ }^{\circ} \mathrm{C}$ (day/night) with daily irrigation; and (3) drought-stressed plants, $25 / 19^{\circ} \mathrm{C}$ (day/light) without watering. All treatments remained for 12 days, and plants were then collected for further analysis. The experiments were conducted in four replicates.

\subsection{Determination of Plant Growth and Biomass, Relative Water Content, and Gas-Exchange Attributes}

The shoot and root length of the collected wheat plants were recorded using a measuring scale. Shoot and root fresh weights were also calculated. Leaf relative water content (RWC) was measured as mentioned by Yamasaki and Dillenburg [47]. Stomatal conductance $\left(g_{s}\right)$, leaf net photosynthesis rate $\left(P_{n}\right)$, and transpiration rate $(E)$ were determined by a gas exchange system (ADC BioScientific, Hoddesdon, UK) at 10:30 a.m., as explained by Holá et al. [48].

\subsection{Measurement of Chlorophyll, Proline, Soluble Protein, and Soluble Sugars Contents}

Leaf total chlorophyll content was calculated, as previously reported by Arnon [49]. Briefly, fresh leafy tissues $(0.1 \mathrm{~g})$ were homogenized in dimethyl sulfoxide and maintained in darkness for 2 days. The absorbance of homogenate was spectrophotometrically recorded at 645 and $663 \mathrm{~nm}$. Leafy proline content was estimated, as previously stated by Bates et al. [50], and absorbance was read at $520 \mathrm{~nm}$. To calculate leaf soluble proteins content and sugars content, a leaf sample was extracted in $100 \mathrm{mM}$ Tris buffer and then centrifuged at the highest speed for $10 \mathrm{~min}$. The soluble proteins content was determined using the method reported by Bradford [51]. The soluble sugar content was calculated as mentioned by Dey [52].

\subsection{Measurement of Contents of Hydrogen Peroxide, Electrolyte Leakage, and Malondialdehyde}

Hydrogen peroxide $\left(\mathrm{H}_{2} \mathrm{O}_{2}\right)$ content was calculated by macerating $60 \mathrm{mg}$ of leaf tissues in $0.1 \%$ TCA $(0.6 \mathrm{~mL})$. Homogenates were centrifuged at high speed and $\mathrm{H}_{2} \mathrm{O}_{2}$ content was calculated as previously mentioned by Velikova et al. [53]. Electrolyte leakage (EL) was estimated as previously reported by Dionisio-Sese and Tobita [54]. Malondialdehyde (MDA) content was calculated as mentioned by Rao and Sresty [55]. 


\subsection{Determination of Antioxidant Enzyme Activities}

Leaf tissues $(0.6 \mathrm{~g})$ were extracted in phosphate buffer $(0.1 \mathrm{M}, \mathrm{pH} 7.6)$ and EDTA $(0.5 \mathrm{mM})$. The extracts were filtered and then centrifuged at $10,000 \times g$ for $18 \mathrm{~min}$ at $5{ }^{\circ} \mathrm{C}$. The supernatant was then utilized to estimate antioxidant enzymes activities. The activity of catalase (CAT) was measured according to Aebi [56], and absorbance was taken at $240 \mathrm{~nm}$. Activities of peroxidase (POX) and superoxide dismutase (SOD) were investigated according to the method reported by Zhang [57]. Ascorbate peroxidase (APX) activity was determined as reported by Yoshimura et al. [58]. Enzyme activity was expressed as unit per milligram protein (EU mg ${ }^{-1}$ protein).

\subsection{Transcriptional Analysis of Antioxidant and Stress-Responsive Genes}

Quantitative real-time PCR analysis was assayed to estimate the expressions of four antioxidant genes (CAT, POX, Mn-SOD, and APX) and six stress-related genes (ERF5a, DREB1, DREB3, WRKY19, $T I P 2$, and $A Q P 7)$ in wild type and the $\mathrm{T}_{2} A t W R K Y 30$-overexpressing wheat plants subjected to normal, heat, and drought treatments. RNA was extracted and cDNA was synthesized from leafy tissues, as reported above. qRT-PCR reactions were conducted following QuantiTect SYBR Green PCR kit manufacturer protocol. PCR reactions and amplification conditions for the four antioxidant genes and six stress-responsive genes were conducted as mentioned by Sheoran et al. [59] and Gao et al. [41], respectively. Specific primer pairs, previously designed for the antioxidant genes $[59,60]$ and stress-related genes [41], were used in amplification. The wheat Actin gene served as an internal reference [41]. The relative expression level of genes was determined using $2^{-\Delta \Delta C t}$ method.

\subsection{Statistical Analysis}

One-way analysis of variance was conducted for the recorded data using SPSS v. 16 (IBM Cop., Armonk, NY, USA). Values denote the means $\pm \mathrm{SE}(n=4)$ and were significantly different at $p \leq 0.05$.

\section{Results and Discussion}

\subsection{Wheat Transformation and Molecular Analysis of Transgenic Lines}

The genetic engineering approach has shown great potential in improving plant tolerance to environmental factors through overexpressing functional transcription factors in crop species. To investigate whether AtWRKY30 overexpression could promote drought and heat tolerance in wheat, AtWRKY30-overexpressing wheat genotypes were generated by the Agrobacterium-mediated transformation. qRT-PCR analysis of the $\mathrm{T}_{0}$ and $\mathrm{T}_{2}$ wheat transformants revealed five lines overexpressing AtWRKY30 (OE-2, OE-4, OE-6, OE-8, and OE-11) (Figure 1A,B). Two $\mathrm{T}_{2}$ lines (OE-4, OE-6) revealed the highest $A t W R K Y 30$ expression level and were therefore used for stress analysis.

(A)

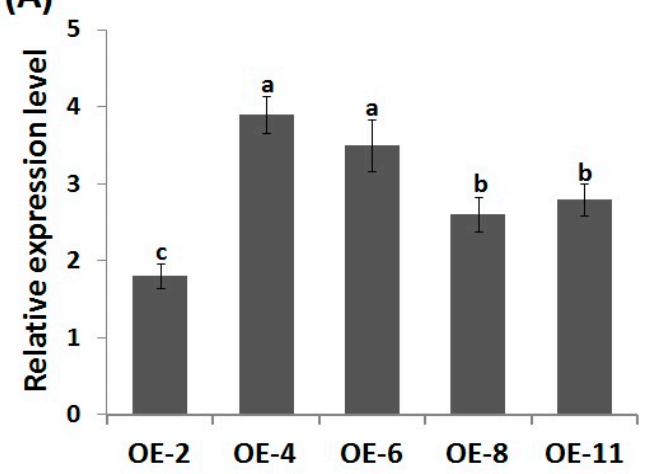

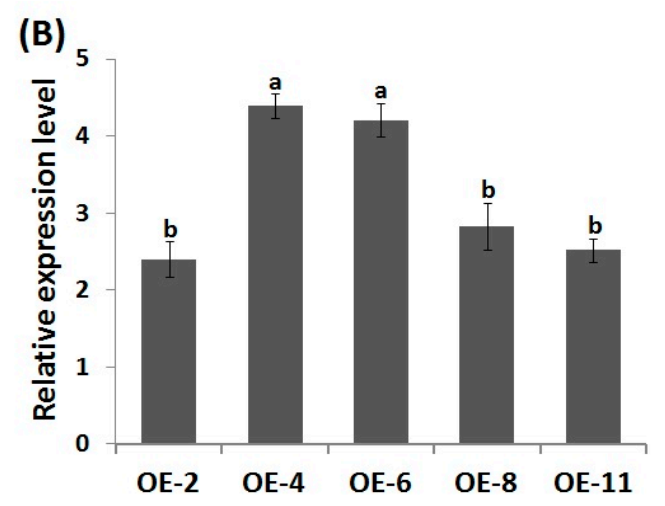

Figure 1. AtWRKY30 relative expression in $\mathrm{T}_{0}(\mathbf{A})$ and $\mathrm{T}_{2}(\mathbf{B})$ overexpressed wheat lines using quantitative real-time PCR (qRT-PCR). 


\subsection{AtWRKY30 Overexpression in Wheat Promotes Plant Growth and Biomass under Heat and Drought Conditions}

AtWRKY30 overexpression effect on wheat growth and biomass was investigated. Non-significant, slight differences in shoot fresh weight, shoot length, root fresh weight, and root length were observed in all wheat lines under normal growth conditions (Table 1). On the contrary, upon exposure to heat and drought stress treatments, remarkable decreases in all growth and biomass traits were detected for the wild-type and transformed wheat plants as compared with normal conditions. Wheat transgenic plants showed significantly higher increases in shoot fresh weight, shoot length, root fresh weight, and root length as compared to wild type plants (Table 1). Results reveal that AtWRKY30 overexpression improved wheat resistance to heat and drought stress and promoted root and shoot growth.

Table 1. Growth and biomass of the wild type and AtWRKY30-overexpressing wheat plants grown under normal, heat, and drought stress conditions.

\begin{tabular}{cccccc}
\hline Treatments & Lines & SL (cm/plant) & RL (cm/plant) & SFW (g/plant) & RFW (g/plant) \\
\hline \multirow{2}{*}{ Normal } & WT & $31.11 \pm 1.13 \mathrm{a}$ & $23.22 \pm 1.32 \mathrm{a}$ & $2.81 \pm 0.11 \mathrm{a}$ & $2.13 \pm 0.17 \mathrm{a}$ \\
& OE-4 & $32.21 \pm 1.67 \mathrm{a}$ & $24.81 \pm 1.18 \mathrm{a}$ & $2.98 \pm 0.25 \mathrm{a}$ & $2.41 \pm 0.21 \mathrm{a}$ \\
& OE-6 & $31.19 \pm 1.81 \mathrm{a}$ & $24.44 \pm 1.13 \mathrm{a}$ & $3.02 \pm 0.18 \mathrm{a}$ & $2.32 \pm 0.18 \mathrm{a}$ \\
Heat & WT & $25.11 \pm 1.62 \mathrm{~b}$ & $16.35 \pm 1.38 \mathrm{~b}$ & $2.17 \pm 0.12 \mathrm{~b}$ & $1.79 \pm 0.17 \mathrm{~b}$ \\
& OE-4 & $30.71 \pm 1.42 \mathrm{a}$ & $22.11 \pm 1.59 \mathrm{a}$ & $2.76 \pm 0.16 \mathrm{a}$ & $2.11 \pm 0.18 \mathrm{a}$ \\
& OE-6 & $29.11 \pm 1.51 \mathrm{a}$ & $21.62 \pm 1.57 \mathrm{a}$ & $2.66 \pm 0.12 \mathrm{a}$ & $2.13 \pm 0.21 \mathrm{a}$ \\
Drought & WT & $21.31 \pm 1.12 \mathrm{~b}$ & $12.66 \pm 1.22 \mathrm{~b}$ & $2.04 \pm 0.22 \mathrm{~b}$ & $1.44 \pm 0.11 \mathrm{~b}$ \\
& OE-4 & $27.13 \pm 1.11 \mathrm{a}$ & $16.99 \pm 1.04 \mathrm{a}$ & $2.19 \pm 0.16 \mathrm{a}$ & $1.83 \pm 0.21 \mathrm{a}$ \\
& OE-6 & $26.51 \pm 1.32 \mathrm{a}$ & $17.11 \pm 1.12 \mathrm{a}$ & $2.17 \pm 0.21 \mathrm{a}$ & $1.85 \pm 0.17 \mathrm{a}$ \\
\hline
\end{tabular}

SL, shoot length; RL, root length; RFW, root fresh weight; SFW, shoot fresh weight; WT, wild-type; OE, overexpressing plants. Values represent means $\pm \mathrm{SE}(n=4)$. Different letters next to the numbers under the same treatment denote significant difference between lines $(p \leq 0.05)$.

\subsection{AtWRKY30 Overexpression in Wheat Enhances Gas Exchange and Leaf Relative Water Content under Heat and Drought Stress Conditions}

Gas-exchange attributes are adversely influenced by the negative impacts of environmental stresses [6]. Moreover, the leaf relative water content reveals the plants water status balance [61,62]. Decreases in the relative water content stimulate osmotic stress and limit plant growth [63]. To investigate whether the AtWRKY30 gene transformed into wheat could enhance gas exchange characteristics and leaf relative water content in this study, the transpiration rate, photosynthetic rate, stomatal conductance, and leaf relative water content were measured in the wild type and transgenic wheat genotypes under heat and drought stress (Figure 2A-D). Under normal conditions, no significant difference was noticed in gas exchange parameters or leaf relative water content in all lines. On the contrary, under heat and stress treatments, reductions in the gas-exchange characteristics and leaf relative water content were observed for all wheat lines as compared with normal conditions. Nevertheless, AtWRKY30-overexpressing wheat genotypes displayed significantly higher increases in gas-exchange characteristics and leaf relative water content as compared to wild type genotype (Figure 2A-D), indicating that the transgenic wheat lines exhibited increased tolerance to heat and drought stress via promoting gas exchange parameters and leaf relative water content. 
(A)

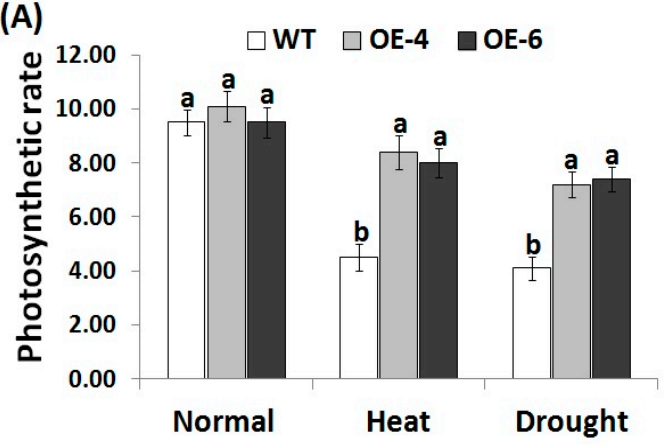

(C)

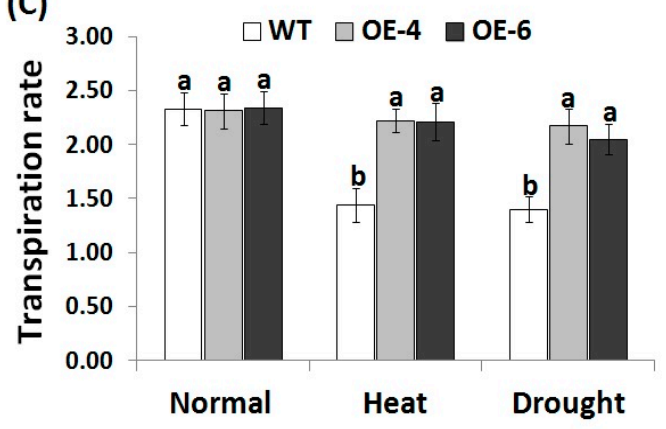

(B)

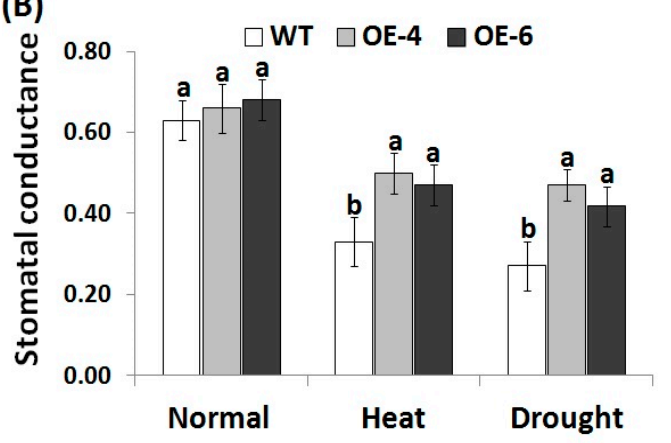

(D)

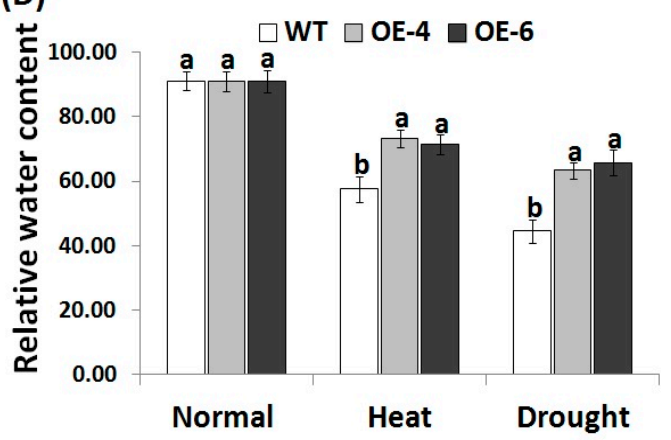

Figure 2. Photosynthesis rate $\left(P_{n}, \mu \mathrm{mol} \mathrm{m} \mathrm{s}^{-1}\right)(\mathbf{A})$, stomatal conductance $\left(g_{s}, \mathrm{~mol} \mathrm{~m}^{2} \mathrm{~s}^{-1}\right)$ (B), transpiration rate $\left(E, \mathrm{mmol} \mathrm{m}^{2} \mathrm{~s}^{-1}\right)(\mathrm{C})$, and relative water content (RWC, \%) (D) of the wild type and transgenic wheat genotypes under normal, heat, and drought stress treatments. Data indicate means \pm SE $(n=4)$. Different letters on the columns represent significant difference $(p \leq 0.05)$.

3.4. AtWRKY30 Overexpression in Wheat Induces the Contents of Chlorophyll and Osmolytes under Heat and Drought Stress

Chlorophyll has a key role in photosynthesis and represents a key indicator for investigating plant abiotic stress tolerance [64]. Moreover, soluble protein, soluble sugar, prolines, and other compatible solutes in plant cells maintain osmotic adjustment under stress conditions $[65,66]$. Proline also serves as an ROS-scavenger, while soluble proteins and sugars mitigate dehydration stress and help maintain the macromolecules structure and function [67]. Therefore, the current study investigated whether AtWRKY30 overexpression could enhance the contents of these osmoprotectans in cells under heat and drought conditions. Under normal growth conditions, non-significantly, slight differences in chlorophyll, proline, soluble protein, and soluble sugar were recorded between the wild-type and the transformed wheat lines (Figure 3A-D). On the contrary, remarkable decrease in chlorophyll content and increases in osmolyte levels were recorded for the wild type and AtWRKY30-overexpressing wheat genotypes under heat and drought stress as compared with the normal growth conditions. AtWRKY30-overexpressing wheat genotypes had higher increases in chlorophyll and osmolytes contents in comparison with the wild type genotype under heat and drought stress treatments (Figure 3A-D), suggesting that the transformed wheat plants maintained better levels of osmolytes and chlorophyll than the wild type. Furthermore, the results reveal that AtWRKY30 overexpression enhanced the osmoregulation ability of wheat transgenic lines to cope with dehydration stress effects. Such results are in harmony with previous findings that showed higher level of osmolytes and chlorophyll in wheat plants overexpressing stress-tolerant genes in comparison the wild type under drought stress [41,43]. 

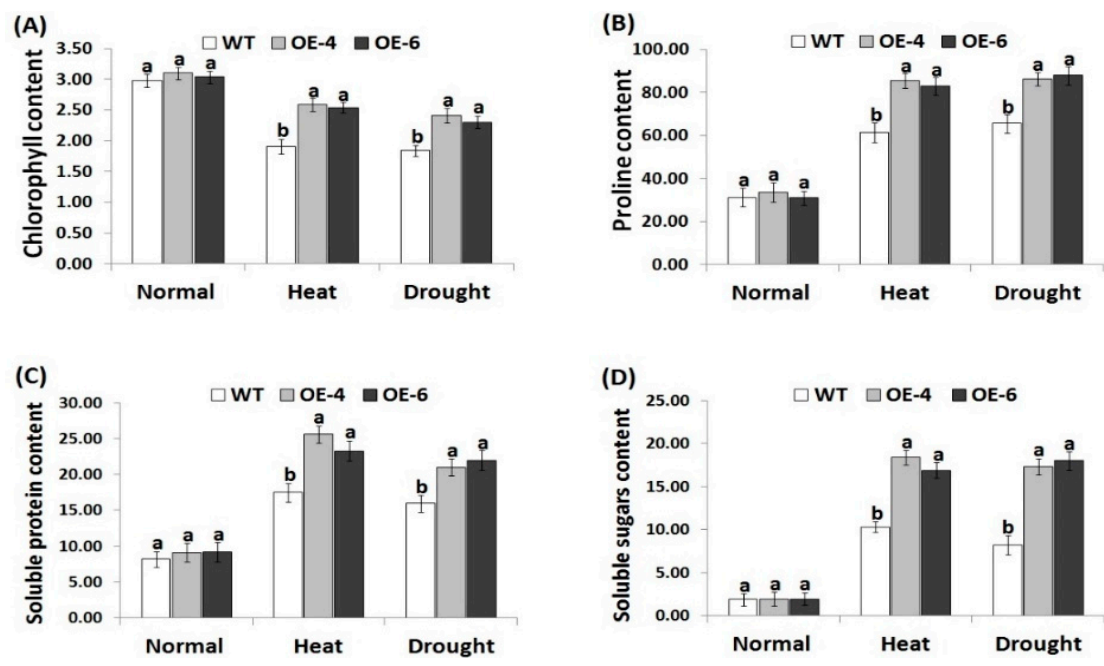

Figure 3. Contents of total chlorophyll ( $\left.\mathrm{mg} \mathrm{g}^{-1} \mathrm{FW}\right)(\mathbf{A})$, proline ( $\left.\mu \mathrm{g} \mathrm{g}^{-1} \mathrm{FW}\right)(\mathbf{B})$, soluble proteins $\left(\mathrm{mg} \mathrm{g}^{-1} \mathrm{FW}\right)(\mathrm{C})$, and soluble sugar $\left(\mathrm{mg} \mathrm{g}^{-1} \mathrm{FW}\right)$ (D) of wild type and transgenic wheat lines under normal, heat, and drought stress treatments. Data indicate means \pm SE $(n=4)$. Different letters on the columns represent significant difference $(p \leq 0.05)$.

3.5. AtWRKY30 Overexpression in Wheat Mitigates Oxidative Stress Markers under Heat and Drought Stress Conditions

Reactive oxygen species stimulate oxidative damage in plant [6]. Electrolyte leakage reflects the cell membrane damage [68]. Additionally, MDA reflects lipid peroxidation end product damage [69]. Therefore, the current study investigated whether AtWRKY30 overexpression in wheat could reduce ROS levels by measuring the levels of MDA, $\mathrm{H}_{2} \mathrm{O}_{2}$, and EL in wild type and transgenic wheat exposed to normal, heat, and drought treatments (Figure $4 \mathrm{~A}-\mathrm{C}$ ). Under normal conditions, no obvious differences in the levels of MDA, $\mathrm{H}_{2} \mathrm{O}_{2}$, and EL were observed between all wheat lines. On the contrary, when exposed to heat and drought conditions, transgenic wheat showed lower levels of the oxidative stress markers in comparison with the wild type plants (Figure 4A-C). The results reveal that AtWRKY30 overexpression in wheat reduces free radicals and the MDA level, thereby promoting wheat tolerance to heat and drought stress.
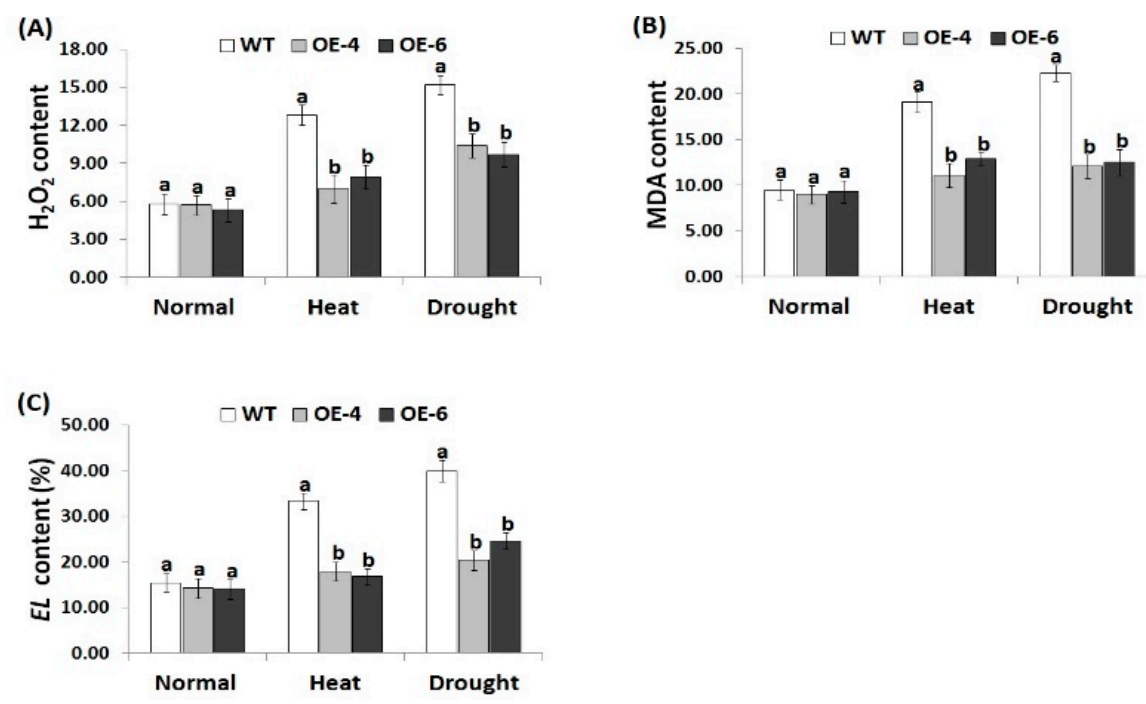

Figure 4. Hydrogen peroxide $\left(\mathrm{H}_{2} \mathrm{O}_{2}, \mu \mathrm{mol} \mathrm{g}{ }^{-1} \mathrm{FW}\right)$ content (A), malondialdehyde (MDA, $\mu \mathrm{mol} \mathrm{g}{ }^{-1}$ FW) content (B), and electrolyte leakage (EL, \%) (C) of wild type and transgenic wheat lines under normal, heat, and drought stress treatments. Data indicate means \pm SE $(n=4)$. Different letters on the columns represent significant difference $(p \leq 0.05)$. 


\subsection{AtWRKY30 Overexpression in Wheat Induces Antioxidant Enzymes Activities under Stress}

Antioxidant enzymes have important roles in scavenging ROS and promoting crop resistance to abiotic stresses [61]. In the current study, the activities of antioxidant enzymes (POX, CAT, APX, and SOD) was investigated in the wild-type and AtWRKY30-overexpressing wheat plants (Figure 5A-D). Non-significantly, slight differences in the four enzyme activities were recorded between wild type and transgenic wheat genotypes. On the contrary, remarkable increments in antioxidant enzyme activities were recorded for wild type and wheat transgenic genotypes under heat and drought treatments when compared to normal condition. Transgenic wheat lines showed higher antioxidant enzyme levels compared to wild type under heat and drought treatments (Figure 5A-D). The results reveal that AtWRKY 30 overexpression stimulated the antioxidant system in transgenic wheat lines to reduce the ROS-induced oxidative damage, thereby improving wheat tolerance to heat and drought conditions. Such results are in harmony with previous reports that showed higher antioxidant enzymes in wheat lines overexpressing stress-tolerant genes under heat or drought conditions $[41,44]$.

(A)

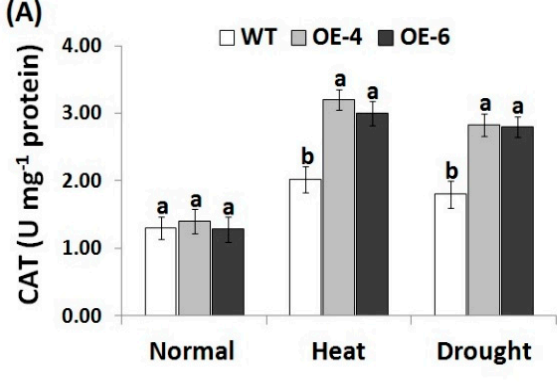

(C)

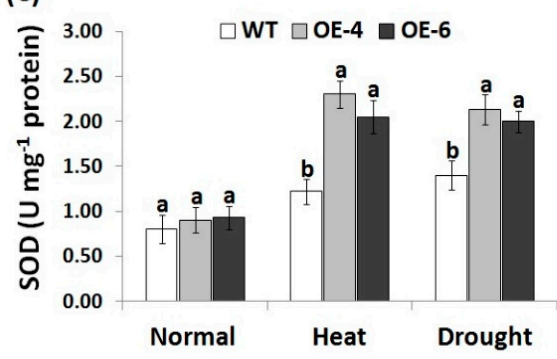

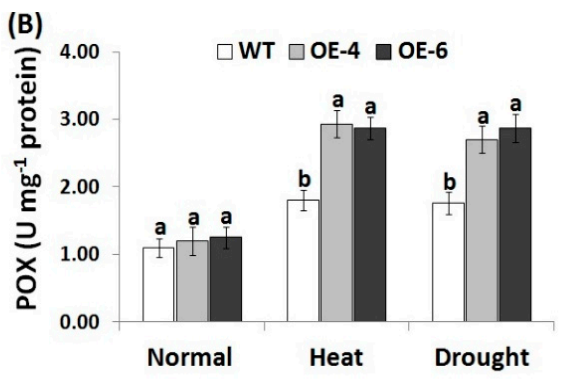

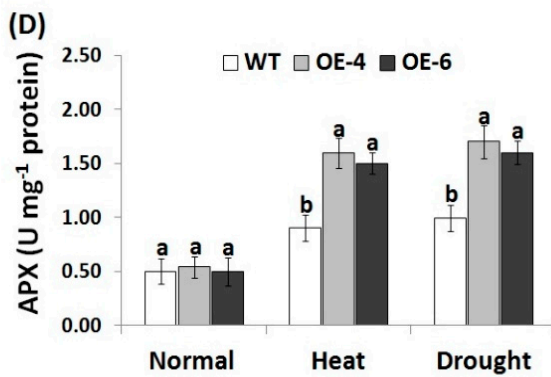

Figure 5. Activity of catalase (CAT) (A), peroxidase (POX) (B), superoxide dismutase (SOD) (C), and ascorbate peroxidase (APX) (D) in wild type and transgenic wheat lines under normal, heat, and drought stress treatments. Data indicate means \pm SE $(n=4)$. Different letters above columns represent significant difference $(p \leq 0.05)$.

\subsection{AtWRKY30 Overexpression in Wheat Induces Stress-Related Gene Expression under Stress Conditions}

To reveal the signaling regulatory roles of AtWRKY30 in heat and drought tolerance mechanisms, expression levels of antioxidant enzymes genes (CAT, POX, Mn-SOD, and $A P X)$ and stress-related genes (ERF5a, DREB1, DREB3, WRKY19, TIP2, and AQP7) were evaluated in the wild-type and the AtWRKY30-overexpressing wheat plants grown under heat and drought treatments using quantitative RT-PCR. Under normal conditions, the wild type and transgenic wheat plants revealed relatively similar expression profiles for antioxidant genes (Figure 6A-D) and stress-responsive genes (Figure 7A-F). On the contrary, under heat and drought conditions, remarkable increments in the transcriptional level of the antioxidants and stress-tolerant genes were detected for the wild type and transgenic wheat genotypes as compared to normal conditions. Nevertheless, AtWRKY30-overexpressing wheat plants showed higher transcriptional level of the antioxidants and stress-responsive genes in comparison with wild type (Figure 6A-D and Figure 7A-F). These results reveal that AtWRKY30 may promote heat and drought stress resistance via inducing the expression of the downstream stress-related genes involved in 
ROS scavenging and defense mechanisms. The results of the antioxidant genes assayed are in harmony with those of the antioxidant enzymes activity. The results are also in concordance with the previous reports that showed higher expression level of stress-responsive genes (ERF5a, DREB1, DREB3, WRKY19, TIP2, and AQP7) in TaWRKY2-overexpressing wheat genotypes in comparison with wild type under drought condition [41].
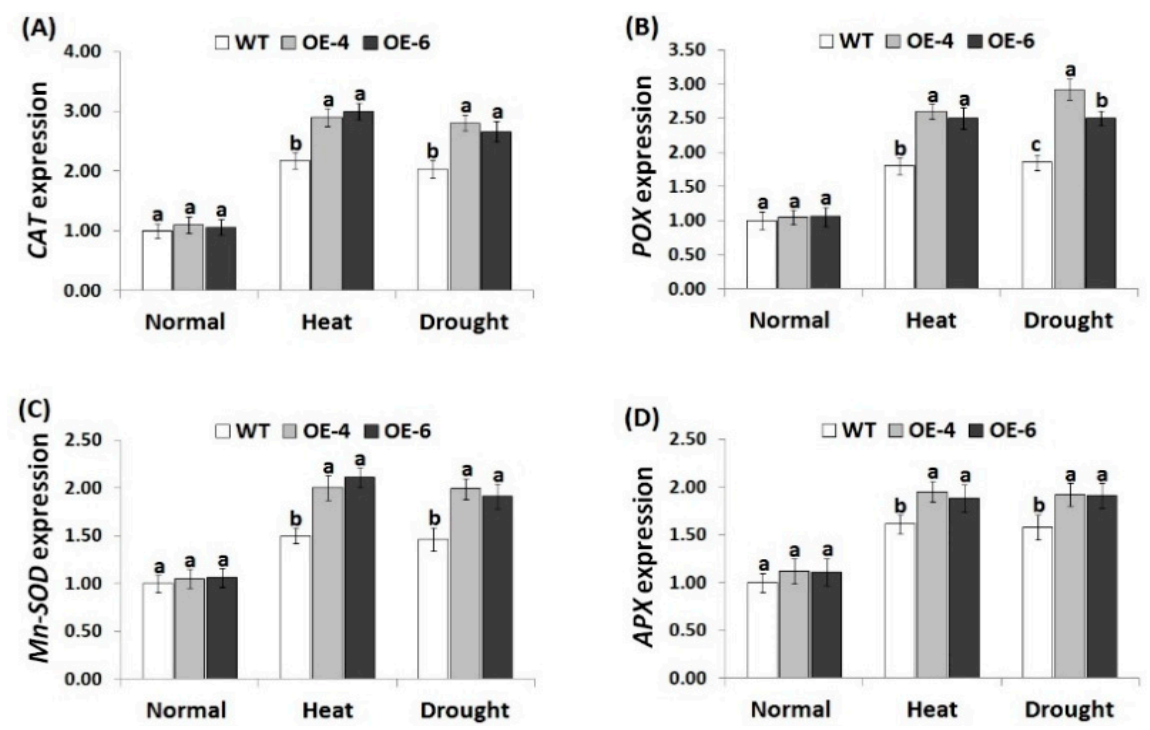

Figure 6. Expression levels of $C A T(\mathbf{A}), P O X(\mathbf{B}), M n-S O D(\mathbf{C})$, and $A P X(\mathbf{D})$ genes in wild type and transgenic wheat lines under normal and stress treatments. Data indicate means $\pm \operatorname{SE}(n=4)$. Different letters above columns represent significant difference $(p \leq 0.05)$.
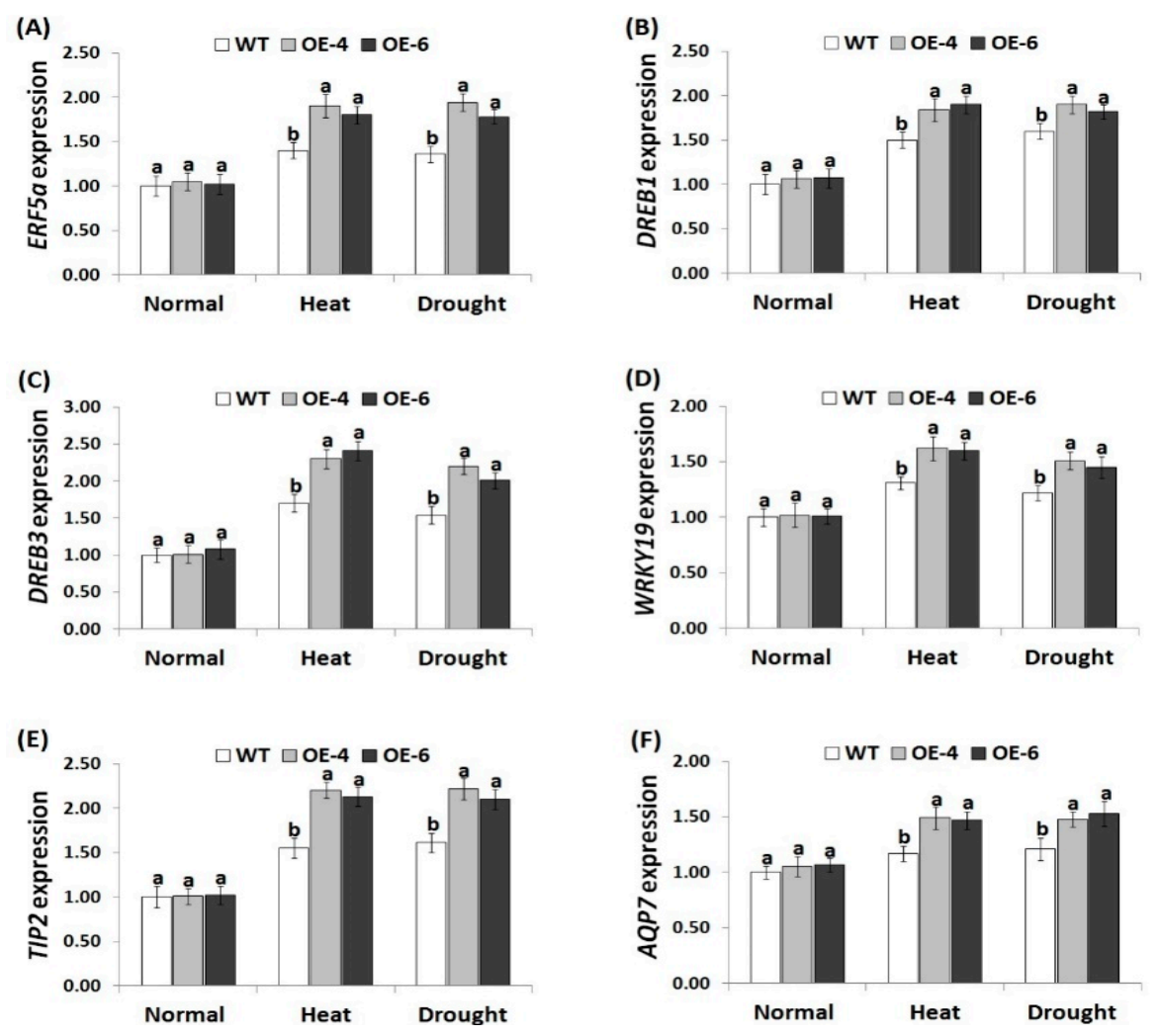

Figure 7. Expression levels of ERF5a (A), DREB1 (B), DREB3 (C), WRKY19 (D), TIP2 (E), and AQP7 (F) genes in wild type and transgenic plants under normal and stress treatments. Data indicate means \pm SE $(n=4)$. Different letters on columns denote significant difference $(p \leq 0.05)$. 


\section{Conclusions}

Wheat productivity is influenced by heat and drought stress worldwide. To promote wheat tolerance to heat and drought stress, the Arabidopsis AtWRKY30 transcription factor was cloned and overexpressed in wheat. Two $T_{2}$ transgenic wheat lines were identified and used to study heat and drought stress tolerance. The findings demonstrate that AtWRKY 30 overexpression could enhance wheat tolerance to heat and drought stress via inducing plant growth, osmolytes biosynthesis, gas-exchange parameters, antioxidant enzymes activity, ROS scavenging, and stress-related gene expression. AtWRKY30 would be a potential candidate for augmenting wheat tolerance to heat and drought stresses.

Author Contributions: M.A.E.-E. designed the study, performed the experiments and data analysis, and wrote, revised, and approved the manuscript. A.A.A.-G., H.M.A., and M.A. revised and approved the manuscript.

Funding: This work was financially supported by King Saud University, Deanship of Scientific Research, College of Science Research Center. The authors would also like to thank Tanta University for the financial support and for facilitating this work.

Conflicts of Interest: The authors declare no conflict of interest.

\section{References}

1. Lamaoui, M.; Jemo, M.; Datla, R.; Bekkaoui, F. Heat and drought stresses in crops and approaches for their mitigation. Front. Chem. 2018, 6, 26. [CrossRef] [PubMed]

2. Li, H.; Wang, Z.; Ke, Q.; Ji, C.Y.; Jeong, J.C.; Lee, H.S.; Lim, Y.P.; Xu, B.; Deng, X.; Kwak, S.S. Overexpression of $\operatorname{codA}$ gene confers enhanced tolerance to abiotic stresses in alfalfa. Plant Physiol. Biochem. 2014, 85, 31-40. [CrossRef] [PubMed]

3. Wani, S.H.; Tripathi, P.; Zaid, A.; Challa, G.S.; Kumar, A.; Kumar, V.; Upadhyay, J.; Joshi, R.; Bhatt, M. Transcriptional regulation of osmotic stress tolerance in wheat (Triticum aestivum L.). Plant Mol. Biol. 2018, 97, 469-487. [CrossRef] [PubMed]

4. El-Esawi, M.; Arthaut, L.; Jourdan, N.; d'Harlingue, A.; Martino, C.; Ahmad, M. Blue-light induced biosynthesis of ROS contributes to the signaling mechanism of Arabidopsis cryptochrome. Sci. Rep. 2017, 7, 13875. [CrossRef] [PubMed]

5. Consentino, L.; Lambert, S.; Martino, C.; Jourdan, N.; Bouchet, P.-E.; Witczak, J.; Castello, P.; El-Esawi, M.; Corbineau, F.; d'Harlingue, A.; et al. Blue-light dependent reactive oxygen species formation by Arabidopsis cryptochrome may define a novel evolutionarily conserved signalling mechanism. New Phytol. 2015, 206, 1450-1462. [CrossRef] [PubMed]

6. Jourdan, N.; Martino, C.; El-Esawi, M.; Witczak, J.; Bouchet, P.-E.; d'Harlingue, A.; Ahmad, M. Blue light dependent ROS formation by Arabidopsis cryptochrome-2 may contribute towards its signaling role. Plant Signal. Behav. 2015, 10, e1042647. [CrossRef] [PubMed]

7. El-Esawi, M.A.; Al-Ghamdi, A.A.; Ali, H.M.; Alayafi, A.A.; Witczak, J.; Ahmad, M. Analysis of genetic variation and enhancement of salt tolerance in french pea. Int. J. Mol. Sci. 2018, 19, 2433. [CrossRef] [PubMed]

8. El-Esawi, M.A.; Alaraidh, I.A.; Alsahli, A.A.; Ali, H.M.; Alayafi, A.A.; Witczak, J.; Ahmad, M. Genetic variation and alleviation of salinity stress in barley. Molecules 2018, 23, 2488. [CrossRef] [PubMed]

9. El-Esawi, M.A.; Alaraidh, I.A.; Alsahli, A.A.; Alamri, S.A.; Ali, H.M.; Alayafi, A.A. Bacillus firmus (SW5) augments salt tolerance in soybean (Glycine max L.) by modulating root system architecture, antioxidant defense systems and stress-responsive genes expression. Plant Physiol. Biochem. 2018, 132, 375-384. [CrossRef] [PubMed]

10. El-Esawi, M.A.; Alaraidh, I.A.; Alsahli, A.A.; Alzahrani, S.M.; Ali, H.M.; Alayafi, A.A.; Ahmad, M. Serratia liquefaciens KM4 improves salt stress tolerance in maize by regulating redox potential, ion homeostasis, leaf gas exchange and stress-related gene expression. Int. J. Mol. Sci. 2018, 19, 3310. [CrossRef] [PubMed]

11. Zaid, A.; Mohammad, F. Methyl jasmonate and nitrogen interact to alleviate cadmium stress in Mentha arvensis by regulating physio-biochemical damages and ROS detoxification. J. Plant Growth Regul. 2018, 37, 1331-1348. [CrossRef] 
12. El-Esawi, M.A.; Al-Ghamdi, A.A.; Ali, H.M.; Alayafi, A.A. Azospirillum lipoferum FK1 confers improved salt tolerance in chickpea (Cicer arietinum L.) by modulating osmolytes, antioxidant machinery and stress-related genes expression. Environ. Exper. Bot. 2019, 159, 55-56. [CrossRef]

13. El-Esawi, M.A. Micropropagation technology and its applications for crop improvement. In Plant Tissue Culture: Propagation, Conservation and Crop Improvement; Anis, M., Ahmad, N., Eds.; Springer: Singapore, 2016; pp. 523-545.

14. Vwioko, E.; Adinkwu, O.; El-Esawi, M.A. Comparative physiological, biochemical and genetic responses to prolonged waterlogging stress in okra and maize given exogenous ethylene priming. Front. Physiol. 2017, 8 , 632. [CrossRef] [PubMed]

15. Khan, W.; Rayirath, U.P.; Subramanian, S.; Jithesh, M.N.; Rayorath, P.; Hodges, D.M.; Critchley, A.T.; Craigie, J.S.; Norrie, J.; Prithiviraj, B. Seaweed extracts as biostimulants of plant growth and development. J. Plant Growth Regul. 2009, 28, 386-399. [CrossRef]

16. El-Esawi, M.A.; Elansary, H.O.; El-Shanhorey, N.A.; Abdel-Hamid, A.M.E.; Ali, H.M.; Elshikh, M.S. Salicylic acid-regulated antioxidant mechanisms and gene expression enhance rosemary performance under saline conditions. Front. Physiol. 2017, 8, 716. [CrossRef] [PubMed]

17. El-Esawi, M.A. Nonzygotic embryogenesis for plant development. In Plant Tissue Culture: Propagation, Conservation and Crop Improvement; Anis, M., Ahmad, N., Eds.; Springer: Singapore, 2016; pp. 583-598.

18. Tandon, S.; Dubey, A. Effects of Biozyme (Ascophyllum nodosum) biostimulant on growth and development of soybean [Glycine max (L.) Merill]. Commun. Soil. Sci Plant Anal. 2015, 46, 845-858. [CrossRef]

19. El-Esawi, M.A. Somatic hybridization and microspore culture in Brassica improvement. In Plant Tissue Culture: Propagation, Conservation and Crop Improvement; Anis, M., Ahmad, N., Eds.; Springer: Singapore, 2016; pp. 599-609.

20. Mayak, S.; Tirosh, T.; Glick, B.R. Plant growth-promoting bacteria confer resistance in tomato plants to salt stress. Plant Physiol. Biochem. 2004, 42, 565-572. [CrossRef] [PubMed]

21. Elansary, H.O.; Yessoufou, K.; Abdel-Hamid, A.M.E.; El-Esawi, M.A.; Ali, H.M.; Elshikh, M.S. Seaweed extracts enhance salam turfgrass performance during prolonged irrigation intervals and saline shock. Front. Plant. Sci. 2017, 8, 830. [CrossRef] [PubMed]

22. Battacharyya, D.; Babgohari, M.Z.; Rathor, P.; Prithiviraj, B. Seaweed extracts as biostimulants in horticulture. Sci. Hortic. 2015, 196, 39-48. [CrossRef]

23. El-Esawi, M.A.; Alayafi, A.A. Overexpression of rice Rab7 gene improves drought and heat tolerance and increases grain yield in rice (Oryza sativa L.). Genes 2019, 10, 56. [CrossRef] [PubMed]

24. El-Esawi, M.A.; Alayafi, A.A. Overexpression of StDREB2 Transcription Factor Enhances Drought Stress Tolerance in Cotton (Gossypium barbadense L.). Genes 2019, 10, 142. [CrossRef] [PubMed]

25. Dong, J.; Chen, C.; Chen, Z. Expression profiles of the Arabidopsis WRKY gene superfamily during plant defense response. Plant Mol Biol. 2003, 51, 21-37. [CrossRef] [PubMed]

26. Xie, Z.; Zhang, Z.L.; Zou, X.; Huang, J.; Ruas, P.; Thompson, D.; Shen, Q.J. Annotations and functional analyses of the rice WRKY gene superfamily reveal positive and negative regulators of abscisic acid signaling in a leurone cells. Plant Physiol. 2005, 137, 176-189. [CrossRef] [PubMed]

27. Pandey, S.P.; Somssich, I.E. The role of WRKY transcription factors in plant immunity. Plant Physiol. 2009, 150, 1648-1655. [CrossRef] [PubMed]

28. Sun, Y.; Niu, Y.; Xu, J.; Li, Y.; Luo, H.; Zhu, Y.; Liu, M.; Wu, Q.; Song, J.; Sun, C.; et al. Discovery of WRKY transcription factors through transcriptome analysis and characterization of a novel methyl jasmonate-inducible PqWRKY1 gene from Panax quinquefolius. Plant Cell Tissue Organ Cult. 2013, 114, $269-277$. [CrossRef]

29. Miao, Y.; Laun, T.; Zimmermann, P.; Zentgraf, U. Targets of the WRKY53 transcription factor and its role during leaf senescence in Arabidopsis. Plant Mol. Biol. 2004, 55, 853-867. [CrossRef] [PubMed]

30. Johnson, C.S.; Kolevski, B.; Smyth, D.R. TRANSPARENT TESTA GLABRA2, a trichome and seed coat development gene of Arabidopsis, encodes a WRKY transcription factor. Plant Cell. 2002, 14, 1359-1375. [CrossRef] [PubMed]

31. Wang, C.; Deng, P.; Chen, L.; Wang, X.; Ma, H.; Hu, W. A wheat WRKY transcription factor TaWRKY10 confers tolerance to multiple abiotic stresses in transgenic tobacco. PLoS ONE 2013, 8, e65120. [CrossRef] [PubMed] 
32. Zhou, L.; Wang, N.N.; Gong, S.Y.; Lu, R.; Li, Y.; Li, X.B. Overexpression of a cotton (Gossypium hirsutum) WRKY gene, GhWRKY34, in Arabidopsis enhances salt-tolerance of the transgenic plants. Plant Physiol. Biochem. 2015, 96, 311-320. [CrossRef] [PubMed]

33. Xiu, H.; Nuruzzaman, M.; Guo, X.; Cao, H.; Huang, J.; Chen, X.; Wu, K.; Zhang, R.; Huang, Y.; Luo, J.; et al. Molecular cloning and expression analysis of eight $\operatorname{PgWRKY}$ genes in Panax ginseng responsive to salt and hormones. Int. J. Mol. Sci. 2016, 17, 319. [CrossRef] [PubMed]

34. Wu, X.; Shiroto, Y.; Kishitani, S.; Ito, Y.; Toriyama, K. Enhanced heat and drought tolerance in transgenic rice seedlings overexpressing OsWRKY11 under the control of HSP101 promoter. Plant Cell Rep. 2009, 28, 21-30. [CrossRef] [PubMed]

35. Yan, H.; Jia, H.; Chen, X.; Hao, L.; An, H.; Guo, X. The cotton WRKY transcription factor GhWRKY17 functions in drought and salt stress in transgenic Nicotiana benthamiana through ABA signaling and the modulation of reactive oxygen species production. Plant Cell Physiol. 2014, 55, 2060-2076. [CrossRef] [PubMed]

36. Chu, X.; Wang, C.; Chen, X.; Lu, W.; Li, H.; Wang, X.; Hao, L.; Guo, X. The cotton WRKY gene GhWRKY41 positively regulates salt and drought stress tolerance in transgenic Nicotiana benthamiana. PLoS ONE 2015, 10, e0143022. [CrossRef] [PubMed]

37. Niu, C.F.; Wei, W.; Zhou, Q.Y.; Tian, A.G.; Hao, Y.J.; Zhang, W.K.; Ma, B.; Lin, Q.; Zhang, Z.B.; Zhang, J.S.; et al. Wheat WRKY genes TaWRKY2 and TaWRKY19 regulate abiotic stress tolerance in transgenic Arabidopsis plants. Plant Cell Environ. 2012, 35, 1156-1170. [CrossRef] [PubMed]

38. Qin, Y.; Tian, Y.; Liu, X. A wheat salinity-induced WRKY transcription factor TaWRKY93 confers multiple abiotic stress tolerance in Arabidopsis thaliana. Biochem. Biophys. Res. Commun. 2015, 464, 428-433. [CrossRef] [PubMed]

39. Wang, K.; Wu, Y.-H.; Tian, X.-Q.; Bai, Z.-Y.; Liang, Q.-Y.; Liu, Q.-L.; Pan, Y.-Z.; Zhang, L.; Jiang, B.-B. Overexpression of $\operatorname{DgWRKY} 4$ enhances salt tolerance in chrysanthemum seedlings. Front. Plant Sci. 2017, 8, 1592. [CrossRef] [PubMed]

40. Scarpeci, T.E.; Zanor, M.I.; Mueller-Roeber, B.; Valle, E.M. Overexpression of AtWRKY30 enhances abiotic stress tolerance during early growth stages in Arabidopsis thaliana. Plant Mol. Biol. 2013, 83, 265-277. [CrossRef] [PubMed]

41. Gao, H.; Wang, Y.; Xu, P.; Zhang, Z. Overexpression of a WRKY transcription factor TaWRKY2 enhances drought stress tolerance in transgenic wheat. Front. Plant Sci. 2018, 9, 997. [CrossRef] [PubMed]

42. Yu, T.F.; Xu, Z.S.; Guo, J.K.; Wang, Y.X.; Abernathy, B.; Fu, J.D.; Chen, X.; Zhou, Y.B.; Chen, M.; Ye, X.G.; et al. Improved drought tolerance in wheat plants overexpressing a synthetic bacterial cold shock protein gene SeCspA. Sci. Rep. 2017, 7, 44050. [CrossRef] [PubMed]

43. Li, L.; Zheng, M.H.; Deng, G.B.; Liang, J.J.; Zhang, H.L.; Pan, Z.F.; Long, H.; Yu, M. Overexpression of AtHDG11 enhanced drought tolerance in wheat (Triticum aestivum L.). Mol. Breed. 2016, 36, 23. [CrossRef]

44. Zang, X.; Geng, X.; Wang, F.; Liu, Z.; Zhang, K.; Zhao, Y.; Tian, X.; Ni, Z.; Yao, Y.; Xin, M.; et al. Overexpression of wheat ferritin gene TaFER-5B enhances tolerance to heat stress and other abiotic stresses associated with the ROS scavenging. BMC Plant Biol. 2017, 17, 14. [CrossRef] [PubMed]

45. Zang, X.; Geng, X.; He, K.; Wang, F.; Tian, X.; Xin, M.; Yao, Y.; Hu, Z.; Xin, M.; Sun, Q.; et al. Overexpression of the wheat (Triticum aestivum L.) TaPEPKR2 gene enhances heat and dehydration tolerance in both wheat and Arabidopsis. Front. Plant Sci. 2018, 9, 1710. [CrossRef] [PubMed]

46. Liang, Z.; Ma, D.; Tang, L.; Hong, Y.; Luo, A.; Zhou, J.; Dai, X. Expression of the spinach betaine aldehyde dehydrogenase $(B A D H)$ gene in transgenic tobacco plants. Chin. J. Biotechnol. 1997, 13, 153. [PubMed]

47. Yamasaki, S.; Dillenburg, L.C. Measurements of leaf relative water content in Araucaria angustifolia. Rev. Bras. Fisiol. Veg. 1999, 11, 69-75.

48. Holá, D.; Benešová, M.; Honnerová, J.; Hnilička, F.; Rothová, O.; Kočová, M.; Hniličková, H. The evaluation of photosynthetic parameters in maize inbred lines subjected to water deficiency: Can these parameters be used for the prediction of performance of hybrid progeny? Photosynthetica 2010, 4, 545-558. [CrossRef]

49. Arnon, D.I. Copper enzymes in isolated chloroplasts. Polyphenoloxidase in Beta vulgaris. Plant Physiol. 1949, 24, 1-15. [CrossRef] [PubMed]

50. Bates, L.S.; Waldren, R.P.; Teare, I.D. Rapid determination of free proline for water-stress studies. Plant Soil. 1973, 39, 205-207. [CrossRef] 
51. Bradford, M.M. A rapid and sensitive method for the quantification of microgram quantities of protein utilizing the principle of protein dye binding. Anal. Biochem. 1976, 72, 248-254. [CrossRef]

52. Dey, P.M. Oligosaccharides. In Methods in Plant Biochemistry, Carbohydrates; Dey, P.M., Ed.; Academic Press: London, UK, 1990; Volume 2, pp. 189-218.

53. Velikova, V.; Yordanov, I.; Edreva, A. Oxidative stress and some antioxidant systems in acid rain-treated bean plants: Protective role of exogenous polyamines. Plant Sci. 2000, 151, 59-66. [CrossRef]

54. Dionisio-Sese, M.L.; Tobita, S. Antioxidant responses of rice seedlings to salinity stress. Plant Sci. 1998, 135, 1-9. [CrossRef]

55. Rao, K.V.M.; Sresty, T.V.S. Antioxidative parameters in the seedlings of pigeon pea (Cajanus cajan L. Millspaugh) in response to Zn and Ni stresses. Plant Sci. 2000, 157, 113-128.

56. Aebi, H. Catalase in vitro. Method Enzymol. 1984, 105, 121-126.

57. Zhang, X.Z. The measurement and mechanism of lipid peroxidation and SOD, POD and CAT activities in biological system. In Research Methodology of Crop Physiology; Zhang, X.Z., Ed.; Agriculture Press: Beijing, China, 1992; pp. 208-211.

58. Yoshimura, K.; Yabuta, Y.; Ishikawa, T.; Shigeoka, A. Expression of spinach ascorbate peroxidase isoenzymes in response to oxidative stresses. Plant Physiol. 2000, 123, 223-233. [CrossRef] [PubMed]

59. Sheoran, S.; Thakur, V.; Narwal, S.; Turan, R.; Mamrutha, H.M.; Singh, V.; Tiwari, V.; Sharma, I. Differential activity and expression profile of antioxidant enzymes and physiological changes in wheat (Triticum aestivum L.) under drought. Appl. Biochem. Biotechnol. 2015, 177, 1282-1298. [CrossRef] [PubMed]

60. Shahabivand, S.; Maivan, H.Z.; Mahmoudi, E.; Soltani, B.M.; Sharifi, M.; Aliloo, A.A. Antioxidant activity and gene expression associated with cadmium toxicity in wheat affected by mycorrhizal fungus. Zemdirb.-Agric. 2016, 103, 53-60. [CrossRef]

61. Siddiqui, M.H.; Al-Khaishany, M.Y.; Al-Qutami, M.A.; Al-Whaibi, M.H.; Grover, A.; Ali, H.M.; Al-Wahibi, M.S. Morphological and physiological characterization of different genotypes of faba bean under heat stress. Saudi J. Biol. Sci. 2015, 22, 656-663. [CrossRef] [PubMed]

62. Sekmen, A.H.; Ozgur, R.; Uzilday, B.; Turkan, I. Reactive oxygen species scavenging capacities of cotton (Gossypium hirsutum) cultivars under combined drought and heat induced oxidative stress. Environ. Exp. Bot. 2014, 99, 141-149. [CrossRef]

63. Alexieva, V.; Sergiev, I.; Mapelli, S.; Karanov, E. The effect of drought and ultraviolet radiation on growth and stress markers in pea and wheat. Plant Cell Environ. 2001, 24, 1337-1344. [CrossRef]

64. Nankishore, A.; Farrell, A.D. The response of contrasting tomato genotypes to combined heat and drought stress. J. Plant Physiol. 2016, 202, 75-82. [CrossRef] [PubMed]

65. Ben, K.R.; Abdelly, C.; Savouré, A. Proline, a multifunctional amino-acid involved in plant adaptation to environmental constraints. Biol. Aujourdhui 2012, 206, 291.

66. Chaleff, R.S. Further characterization of picloram tolerant mutants of Nicotinana tabacum. Theor. Appl. Genet. 1980, 58, 91-95. [CrossRef] [PubMed]

67. Wang, F.; Liu, P.; Zhu, J. Effect of magnesium (Mg) on contents of free proline, soluble sugar and protein in soybean leaves. J. Henan Agric. Sci. 2004, 6, 35-38.

68. Bajji, M.; Kinet, J.; Lutts, S. The use of the electrolyte leakage method for assessing cell membrane stability as a water stress tolerance test in durum wheat. Plant Growth Regul. 2002, 36, 61-70. [CrossRef]

69. Ganguli, L.J. Lipid peroxidation-DNA damage by malondialdehyde. Mut. Res.-Fund. Mol. Mol. 1999, 424, 83-95.

(C) 2019 by the authors. Licensee MDPI, Basel, Switzerland. This article is an open access article distributed under the terms and conditions of the Creative Commons Attribution (CC BY) license (http:/ / creativecommons.org/licenses/by/4.0/). 